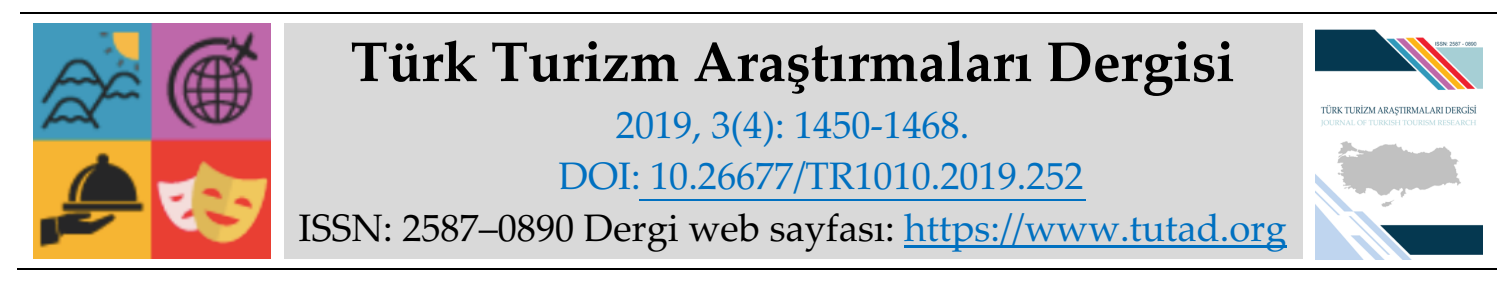

ARASTIRMA MAKALESİ

\title{
İşgören Mutluluk Düzeylerinin İş Tatmini ve İş Performansı Üzerine Etkileri: Konaklama İşletmelerinde Bir İnceleme*
}

Gizem BİÇEN, Gazi Üniversitesi, Sosyal Bilimler Enstitüsü, Ankara, e-posta: gizemsoyel@gmail.com ORCID: https://orcid.org/0000-0001-8811-7630

Doç. Dr. Hakan KOÇ, Ankara Hacı Bayram Veli Üniversitesi, Turizm Fakültesi, Ankara, e-posta: hakan.koc@hbv.edu.tr

ORCID: https://orcid.org/0000-0003-2850-0472

\section{Öz}

$\mathrm{Bu}$ araştırmanın amacı, işgörenlerin mutluluk düzeyleri ile işten elde ettikleri tatmin ve işgören performansı arasındaki ilişkinin varlığını ve yönünü belirlemek, aralarındaki etkileşimi tespit etmeye çalışmaktır. Mutluluk düzeylerinin iş tatmini ve işgören performansı üzerinde ne tür bir etki oluşturduğu incelenmeye çalışmaktır. Araştırmanın uygulanmasında ise nicel araştırma yöntemi olan anket tekniği kullanılmıştır. Anket çalışmasında, kişisel bilgi formu, iş tatmini ve iş performans düzeyi belirlemeye yönelik ölçekler kullanılmıştır. Anket aracılığıyla toplanan verilerin istatiksel programlar ile analizleri yapılarak, katılımcıların demografik özelliklerine (cinsiyet, yaş, öğrenim, medeni durum, gelir düzeyi) verdikleri cevaplar doğrultusunda, frekans analizi; iş tatmini ile demografik özelliklere ilişkin T testi ve OXFORD mutluluk ölçeği, iş tatmini ve iş performansı arasındaki ilişkiyi belirlemek için korelasyon analizi ve korelasyon analizi yapılmıştır. Araştırma sonuçlarına göre turizm işgörenlerinin mutluluk düzeyleri, iş tatminleri ve çalışma performansları arasında anlamlı ilişki tespit edilmiştir.

*Bu makale Gizem BİÇEN'in yüksek lisans tezinden üretilmiştir.

Anahtar Kelimeler: İşgören Mutluluk Düzeyi, İş Tatmini, İşgören Performansı.

Makale Gönderme Tarihi: 03.06.2019

Makale Kabul Tarihi: 04.10.2019

\section{Önerilen Atıf:}

Biçen, G. ve Koç, H. (2019). İşgören Mutluluk Düzeylerinin İş Tatmini ve İş Performansı Üzerine Etkileri: Konaklama İşletmelerinde Bir İnceleme, Türk Turizm Araştırmaları Dergisi, 3(4): 1450-1468.

(c) 2019 Türk Turizm Araştırmaları Dergisi. 


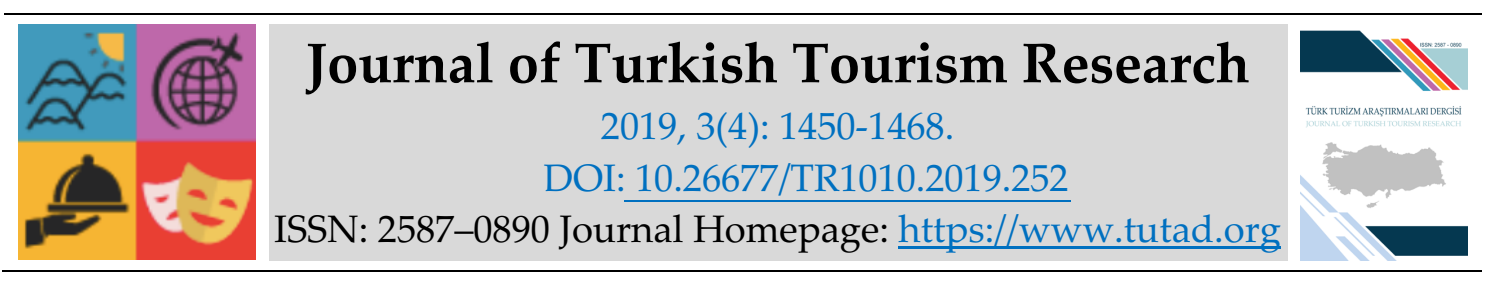

\title{
RESEARCH PAPER
}

\section{The Effects of Employee Happiness Levels on Job Satisfaction and Job Performance: A Review of Accommodation Establishments}

\author{
Gizem BİÇEN, Gazi University, Social Sciences Institute, Ankara, e-mail: gizemsoyel@gmail.com \\ ORCID: https://orcid.org/0000-0001-8811-7630
}

Associate Prof. Dr. Hakan KOÇ, Ankara Hacı Bayram Veli University, Faculty of Tourism, Ankara, email: hakan.koc@hbv.edu.tr

ORCID: https://orcid.org/0000-0003-2850-0472

\begin{abstract}
The purpose of this study is to determine the existence and direction of the relationship between the happiness levels of the employees and the satisfaction and employee performance obtained from the job and try to determine the interaction between them. The effect of happiness levels on job satisfaction and employee performance is to be examined. In the application of the study, the quantitative research method, the survey technique, was used. In the questionnaire, scales were used to determine the personal information form, job satisfaction, and job performance level. By analyzing the data collected through the questionnaire with statistical programs, the frequency analysis of the participants according to their demographic characteristics (gender, age, education, marital status, income level); Correlation analysis and correlation analysis were performed to determine the relationship between job satisfaction and demographic characteristics, $\mathrm{T}$ test and OXFORD happiness scale, job satisfaction and job performance. According to the results of the study, a significant relationship was found between the happiness levels, job satisfaction and working performance of the tourism workers.
\end{abstract}

Keywords: Employee Happiness Levels, Job satisfaction, Employee Performance.

Received: 03.06.2019

Accepted: 04.10.2019

\section{Suggested Citation:}

Biçen, G. and Koç, H. (2019). The Effects of Employee Happiness Levels on Job Satisfaction and Job Performance: A Review of Accommodation Establishments, Journal of Turkish Tourism Research, 3(4): 1450-1468.

(C) 2019 Türk Turizm Araştırmaları Dergisi. 


\section{Gíriş}

İnsanlar tarihin ilk dönemlerinden itibaren mutlulukla ilgilenmişlerdir. Bu ilgi doğrultusunda; Mutluluk nedir? Mutluluğun mahiyeti nedir? Mutluluğun belirleyicileri nelerdir? Kalıcı mutluluk sağlanabilir mi? gibi sorulara cevap aranmışlardır. Özetle, insan yaşamının amacı ve buna nasıl ulaşılabileceği sorunu Aristoteles'in de temel sorunu olmuştur (Doğan vd., 2014:48). Aristoteles'e göre "yaşamını kendi tercihine göre yönlendirebilen herkes güzel yaşamak için bir hedef koyar -mevki, ün, zenginlik ya da eğitim- tüm eylemlerini bu hedefe bakarak gerçekleştirir." Bu anlamda mutluluk en genel amaçtır ve insanın bütün diğer amaçlarını kapsar (Aristoteles, 2015:72). Farabi'ye göre ise, insanlığın amacı en yüksek iyiyi bilecek yetkinliği elde edebilmektir. En yüksek iyinin ne olduğunu ayırt etmekle, insan mutluluğun iyi bir amaç olduğunu ayırt etmek aynı şeydir. Çünkü amaçlar çoktur ve amaçların çokluğu mutluluk yolunda insanı ayartabilir (Özgen, 2005:112).

Günümüzde kişilerin hayatlarına dair edinmek istedikleri en önemli amaç ise, mutluluk arayışı veya aynı ifade yerine kullanılan öznel iyi oluştur. Mutluluk insan yaratılışının temelini oluşturmaktadır. Mutluluk arayışı tarih öncesi dönemlerden günümüze kadar gelen insan doğasının en önemli arayışını oluşturmaktadır. Diğer yandan son yıllarda öznel iyi oluş ile ilgili çalışmaların dikkate değer bir biçimde arttığı gözlenmektedir (Yurcu ve Atay, 2015:18). Günümüzde çalışma ortamlarında girilen yoğun rekabet, işletmelerin en önemli kaynağı olan işgücünü stress altına sokmaktadır. Zorluklar ile yüz yüze gelindiğinde kendini gerçekleştirme ve anlamlı bir yaşam için işgörenin potansiyelini vurgulayan kavram ise psikolojik iyi oluştur (Keleş, 2017:155). Özellikle de insan gücüne diğer sektörlerden daha fazla ihtiyaç duyulan turizm sektörü için de işgören mutluluğu ve işgörenin psikolojik açıdan iyi olmasının önemini iyice artmaktadır. Örgütlerin faaliyetleri yerine getirmesinde gerekli olan teknik ve mali bütün faktörlerin yeterli seviyede olması, insan unsurunun olmaması halinde hiçbir anlam taşımamaktadır.

Örgütler için insan kaynağı sadece en değerli kaynağı değil aynı zamanda en önemli zenginliğidir (Karasakaloğlu, 2016:278). İşgörenler bir işe girdiklerinde işyerinin kendisine sağlayacağı koşullara ilişkin birçok konuda sözel ve yazılı anlaşmaya varmakta ve buna bağlı olarak iş sözleşmesi imzalamaktadırlar. Ancak bu anlaşmaların yanında kişilerin söz konusu etmemelerine rağmen, işgörenin işten beklentilerini işyerinin de işgörenden beklentilerini açıklayan psikolojik anlaşmalar vardır. Psikolojik anlaşmalara göre kişi isteklerinin ya da beklentilerinin karşılanmadığını hissettiğinde, işine ve işyerine karşı negatif tutumlar geliştirmesi söz konusu olabilmektedir. Bu noktada, işgörenin iş tatmininin gelişmesinde elde edilenler ile beklentilerin birbiri ile ne kadar örtüştüğü iş tatmininin oluşmasında etkili olduğu ifade edilebilir (Eğinli, 2009:38). Bir işletmenin uzun vadedeki başarısı, işgörenlerinin ne kadar iyi performans gösterdiklerini ölçüm yeteneğiyle ve bu ölçüm sonucunda ulaşılan verileri, mevcut performans standartlarını geliştirmeye yönelik olarak kullanmaları ile sağlanmaktadır. Bu noktada değerleme süreci, bireyin daha işe kabul aşamasında başlayan ve çalışma hayatı süresince de belli amaçlar doğrultusunda ve belli aralıklarla düzenli olarak sürdürülen faaliyetler bütününü ifade etmektedir.

İşletmelerin faaliyet alanları, türü ve kapasiteleri ne olursa olsun, yönetici pozisyonunda görev yapan kişilerin en önemli sorumluluk alanlarından birisi, işgören performansının değerlendirilmesi ve artırılmaya çalışılmasıdır (Kıngır ve Taşkıran, 2006: 196). Bu araştırmanın amacı, işgörenlerin mutluluk düzeyleri ile işten elde ettikleri tatmin ve işgören performansı arasındaki ilişkinin varlığını ve yönünü belirlemek, aralarındaki etkileşimi tespit etmeye çalışmaktır. Mutluluk düzeyinin iş tatmini ve işgören performansı üzerinde ne tür bir etkisi oluşturduğu incelenmeye çalışılacaktır. $\mathrm{Bu}$ kapsamda araştırmaya ilişkin hipotezler aşağıdaki gibi belirlenmiştir:

Hipotez 1: İşgörenlerin mutluluk düzeyleri ile iş tatminleri arasında ilişki vardır.

Hipotez 2: İşgörenlerin iş tatminleri ile çalışma performansları arasında ilişki vardır.

Hipotez 3: İşgörenlerin mutluluk düzeyleri ile çalışma performansları arasında ilişki vardır. 
Hipotez 4: Yaş değişkeni açısından; (a) işgörenlerin mutluluk düzeylerinde, (b) iş tatmini ve (c) performans düzeylerinde farklılaşma vardır.

Hipotez 5: Cinsiyet değişkeni açısından; (a) işgörenlerin mutluluk düzeylerinde, (b) iş tatmini ve (c) performans düzeylerinde farklılaşma vardır.

Hipotez 6: Medeni durum değişkeni açısından; (a) işgörenlerin mutluluk düzeylerinde, (b) iş tatmini ve (c) performans düzeylerinde farklılaşma vardır.

Hipotez 7: Sektördeki çalışma yılı değişkeni açısından; (a) işgörenlerin mutluluk düzeylerinde, (b) iş tatmini ve (c) performans düzeylerinde farklılaşma vardır.

Hipotez 8: İşletmedeki çalışma yılı değişkeni açısından; (a) işgörenlerin mutluluk düzeylerinde, (b) iş tatmini ve (c) performans düzeylerinde farklılaşma vardır.

Hipotez 9: Eğitim değişkeni açısından; (a) işgörenlerin mutluluk düzeylerinde, (b) iş tatmini ve (c) performans düzeylerinde farklılaşma vardır.

Hipotez 10: Yönetici olup olmama değişkeni açısından; (a) işgörenlerin mutluluk düzeylerinde, (b) iş tatmini ve (c) performans düzeylerinde farklılaşma vardır.

Hipotez 11: Departman değişkeni açısından; (a) işgörenlerin mutluluk düzeylerinde, (b) iş tatmini ve (c) performans düzeylerinde farklılaşma vardır.

\section{KAVRAMSAL ÇERÇEVE}

\section{İşgören Mutluluğu}

İnsanlığın doğuşundan bu yana mutluluk kavramı hep ön planda olmuş, mutluluğu anlamaya, yakalamaya, kavramaya çalışmak bireyler için birincil amaç haline gelmiştir. Filozoflar mutluluğu insan eylemleri için güdüleyici ve motive edici bir güç olarak görmüşlerdir. (Uslu, 2018:470).

Mutluluk felsefenin olduğu kadar psikolojinin ve sosyal bilimlerin de üzerinde uğraştığı bir konu olmuştur. Felsefecilerden farklı olarak psikologlar ve sosyal bilimciler sorunlar, sıkıntılar ve mutsuzluk üzerinde daha fazla yoğunlaşıp mutluluk ya da öznel iyi olma değişkenlerini ihmal etmişlerdir. Birçok davranış bilimci insanların ağırlıklı olarak doyumsuz ve mutsuz olduğunu düşünmüştür (Kangal, 2013:215). Diğer yandan mutluluk, psikolojide öznel iyi oluş kavramıla ele alınır. Öznel iyi oluş, bireylerin yaşamlarına dair değerlendirmeleri ve yargıları bildirmektedir (Eryılmaz, 2010:190).

Literatürde mutluluk kavramı “bireyler tarafından beklenen yaşam düzeyi kalitesinin yargılanması" ile ortaya çıkan sonuç şeklinde değerlendirildiği görülmektedir. Bireylerin temel psikolojik ihtiyaçlarını doyurmaları onların iyi olma düzeylerini yükseltmektedir. Bireylerin yaşam kalitelerini değerlemeleri ve iyi bir yaşamları olup olmadığına karar vermeleri kapsamında psikoloji literatüründe "iyi yaşam"; "öznel iyi olma" olarak adlandırılırken, günlük konuşma dilinde ise "mutluluk" olarak adlandırılmaktadır (Çankaya, 2009:24). Yine literatürde, mutluluk kavramına ilişkin hazcılık (hedonizm) ve mutçuluk (eudaimonizm) olmak üzere iki farklı geleneksel bakış olduğu ileri sürülmektedir. Hazcılık yaklaşımı, mutluluk kavramına; hayatın tüm kesitlerindeki olumlu veya olumsuz olayların değerlendirilmesini içeren öznel iyi oluş hali olarak yaklaşmaktadır. Bu doğrultuda, hazcılık yaklaşımı, mutluluğun fiziksel unsurlarla birlikte hayatın diğer alanlarında karşılaşılan etmenlerle çelişkili olduğunu savunmaktadır (Servet, 2017:17).

Diğer yandan bireyler çalışma hayatına başladıktan sonra yaşamının üçte birini iş yerinde geçirmektedir. Dolayısıyla işgörenlerin mutluluğu genel yaşam mutluluğunun önemli bir parçasını oluşturmaktadır. Bu sebeple işgören bireylerin yaşam kalitelerinin artması ve iş verimlerinin yükselmesi için kendi içlerinde doyuma ulaşmaları gerekmektedir. Bu doyum kişinin kendi mutluluğu ile gerçekleşmektedir. İşgörenlerin mutluğu birincil olarak örgütleri ve toplumları ilgilendirmektedir. Değişen ve gelişen yaşam standartları ve fazlalaşan rekabet ortamları için iş yerlerinde mutlu işgörenler 
insan kaynakları açısından avantaj yaratmaktadır. Dolayısıyla bu avantajı elde etmek, işgörenlerin iş performaslarını arttırmak ve ileriye dönük işgören devir hızını düşürmek için mutluluk kavramı oldukça önemli bir yere sahiptir.

Yapılan çalışmalarda ekonomik olarak iyi bir çevrede yaşayan, sosyal güvenceleri bulunan, koyduğu hedeflere ulaşabilecek güce sahip olan bireylerin mutluluk oranlarının daha yüksek olduğu belirlenmiştir. Daha yüksek mutluluk oranına sahip olan bireylerin ise kötü olayların üzerinde çok durmadıkları ve olaylara her zaman iyi taraflarından baktıkları görülmüştür (Akduman ve Yüksekbilgili, 2015:417).

İlgili alan yazında mutlu işgörenlerin daha yüksek performans gösterdiğini destekleyen birçok araştırma mevcuttur. Araştırmalar, mutluluk düzeyi yüksek olan bireylerin yalnızca kendilerini iyi hissetmekle kalmayıp, kişilerarası ilişkilerinde daha başarılı olduklarını (Terzi, 2017:477), performanslarının ve hayattan aldıkları doyumun arttı̆̆ını, bağışıklık sistemlerinin güçlendiğini, iş yaşamında daha verimli olduklarını ortaya koymaktadır (Certel, vd., 2015:309).

\section{İş Tatmini}

İş tatmini kavramı, ilk defa 1920'li yıllarında araştırmalara konu olmaya başlamış, ancak konunun gerekliliği 1940'lı yıllarda tam olarak anlaşılmıştır (Eğinli, 2009:36). İnsan yaşamında iş hayatı ve bir işe sahip olma anlayışı önemli bir yere sahiptir. Çünkü insanın içinde yaşadığı çevrelerden biri iş çevresi ile beraber, insan yaşamının yaklaşık üçte biri çalışarak geçmektedir. İşin bireyler için önemli olmasının sebebi yerine getirdiği fonksiyonlardan kaynaklanmaktadır. İş, bireylerin sosyal, psikolojik ve ekonomik düzeyde çeşitli ihtiyaçlarını karşılamasına imkan tanır. Bu sebeple kişilerin yaşamlarında önemli bir rol oynamaktadır (Köroğlu, 2011:16). Yapılan işin karşılığı olarak elde edilen ücret, mal, hizmet veya bilgi, yapılan işin ekonomi anlamındaki boyutunu ifade etmektedir. Kişiler çalıştıkları işlerde ekonomik bir değer yaratmaktadır. Çalışma karşılığı olarak kazanılan para, yiyecek, barınma, ulaşım ve benzeri giderlerin karşılanmasında kullanılmaktadır (Köroğlu, 2011:16).

En temel "iş tatmini" tanımları Landy ve Locke tarafından yapılmıştır. İş tatmini, bireyin genel olarak çalışma yaşamından aldığı hazzı ve mutluluğu ifade etmektedir. Landy, iş tatminini işe ait bireysel değerleme sonucu ortaya çıkan duygusal durum olarak tanımlamaktadır (Keser, 2005:79).

İş tatmini, iş şartlarının (işin kendisi, yönetimin tutumu) ya da işten elde edilen sonuçların (ücret, iş güvenliği) kişisel bir değerlemesidir ve bireyin normlar, değerler, beklentiler sisteminden geçerek işlenen iş ve iş koşullarına ilişkin algılamalarına karşı geliştirdiği içsel tepkilerden oluşmaktadır. Bu anlamda iş tatmini, "bireyin çalışma ortamına karşı reaksiyonu" dur (Aşan ve Erenler, 2008:205).

İş tatmini, işgörenlerin bedensel ve zihinsel sağlıkları yanında, bireysel fizyolojik ve ruhsal duyguların bir belirtisidir. İş tatmini denince, işten elde edilen maddi çıkarlar ile işgörenin beraberce çalışmasından zevk aldığı iş arkadaşları ve ürün meydana getirmenin sağladığı bir mutluluk akla gelmektedir (Konuk, 2006:160).

İş tatmini dinamik bir yapı arz eder. Yöneticiler bir kez iş tatmini sağlayıp sonra bu konuyu birkaç yıl gözden uzak tutamazlar. İş tatmini hızlı elde edilebildiği gibi, hızla iş tatminsizliğine dönüşebilir. Bir örgütte koşulların bozulduğunu gösteren en önemli kanıt iş tatmininin düşük olmasıdır (Aşık, 2010:35). İş tatmini işgörenlerin işe ya da işin belirli kısımlarına karşı duygusal olarak verdikleri olumlu veya olumsuz tepkinin karşılığıdır.

Yöneticiler, örgütlerinde işgörenlerin iş tatmininin yüksek olmasını istemektedirler. Bundan dolayı iş tatminini sağlamak ve yükseltmek için de olanaklarına ve tecrübelerine göre çaba harcamaktadırlar. Bireysel ve örgütsel hedeflere ulaşılmasında önemli bir etken olan iş tatmininin sağlanması ve yükseltilmesi için her şeyden önce iş tatminini etkileyen faktörler hakkında sağlıklı bilgi sahibi olmak gerekmektedir (Akınc1, 2002:4). 
İş tatmininin sağlanması örgütlerdeki işgörenlerin faaliyetlerinin kalitesinde önemli etkiye sahiptir. Bu nedenle yöneticiler işgörenlerin iş tatminlerini artırmak için çeşitli yönetsel yöntem ve teknik kullanmaktadır. İş tatminini yükseltici çabaların sonucunda yüksek seviyede tatmine ulaşmış işgörenlerin performanslarında olumlu gelişmeler sağlanabilmektedir (Koç, Yazıcıoğlu ve Hatipoğlu, 2009:14).

\section{İşgören Performansı}

İşgörenlerin performansı, işletmelerin başarısı ve gelecek planları açısından son derece önemlidir. İşgörenlerinden beklenilen düzeyde performans sergilemesini isteyen işletmelerin doğru tercihler yaparak bu doğrultuda adım atması gerekmektedir (Uludağ, 2018:179). Bu açıdan performans bir işgörenin belirli bir zaman dilimi içerisinde kendisine verilen görevi yerine getirmek suretiyle elde ettiği sonuçlardır. Bu sonuçlar olumlu ise personelin üstlendiği görevi başarıyla yerine getirdiği ve yüksek performans sergilediği anlaşılır. Sonuçlar olumsuz ise, işgörenin başarılı olmadığı ve düşük performans sergilediği kabul edilir (Kahya, 2013:36).

Bir işgörenin gereksinim ve ihtiyaçlarını tamamlamak için bir işletmede görev ve sorumluluklar üstlenip yerine getirmesi sonucunda, istediklerini elde etmek için zaman ve çaba harcamasına işgören performansı denilmektedir. Başarı veya başarım terimleriyle de ifade edilebilen performans, işgörenin kendisi için tanımlanan özellik ve yeteneklerine uygun olan işin kabul edilebilir sınırlar içinde gerçekleştirilmesidir (Köroğlu, 2011: 184).

İşgücü, işletmeler için vazgeçilmez bir unsurdur. Rekabetin kıyasıya olduğu ve değişimin hızla gerçekleştiği küresel pazarlarda, işletmelerin üstünlük elde etmesinde en büyük yardımcı işgörendir. $\mathrm{Bu}$ nedenle, insan kaynakları yönetimin bir parçası olan işgören performansı işletmenin rekabet üstünlüğü elde etmesi ve sürekli geliştirilmesi amacıyla kullanılabilir. Bununla birlikte işgörenlerin performansı müşterilerin memnuniyetleri bakımından önem taşımaktadır. Özellikle müşteri ile işgörenlerin birebir iletişimde bulunduğu turizm gibi sektörlerde işgören performansı müşterilerin tekrar tekrar aynı işletmeyi tercih etmelerinde büyük rol oynamaktadır. İşletmeye belli bir hizmet beklentisi içinde gelen müşterinin algıladığı, yani gerçekte olan hizmetin beklentisine cevap vermesi, hatta beklentisinin de üstünde olması, müşteri memnuniyetini getirmektedir. Eğer işgören kendisinden beklenen performans düzeyini göstermiyorsa işgörende bir takım performans sorunlarının olduğu ortaya çıkacaktır. (Köroğlu, 2011:186):

İşgörenlerin performansı, işletmelerin başarısı ve gelecek planları açısından son derece önemlidir. İşörenlerinden beklenilen düzeyde performans sergilemesini isteyen işletmelerin doğru tercihler yaparak bu doğrultuda adım atması gerekmektedir (Uludağ, 2018:179).

Örgütsel bağlamda başarının anahtarı olan performans artışı kendiliğinden gerçekleşen bir sürecin ürünü değildir. Diğer bir deyişle, performansın stratejik bir konu olarak algılanıp yönetilmesi gerekmektedir (Köroğlu, 2011:187). Yöneticiler öncelikli olarak işgörenin işini tamamlamada göstereceği performansı etkileyebilecek işgörenden ya da diğer nedenlerden kaynaklanan unsurların farkında olması gerekmektedir (Özmutaf, 2007: 44-50).

\section{YÖNTEM}

Araştırmada işgörenlerin mutluluk düzeyi, iş tatmini ve işgören performansı arasındaki ilişki ana hipotez olarak ele alınmıştır. Buna bağlı olarak da alt hipotez geliştirilmiştir. Araştırmanın evrenini Ankara'da faaliyet gösteren 5 yıldızlı konaklama işletmelerindeki işgörenler oluşturmaktadır. Araştırmaya konu olan işgörenlerin tam sayısını belirlemek için işgören sayıları araştırılmış ancak konaklama işletmelerinin gizlilik politikaları nedeniyle herhangi bir veriye ulaşılamamıştır. Bu nedenle; literatür araştırması yapılarak oda başına düşen ortalama işgören sayısı bulunmuş ve otellerin toplam oda sayıları ile çarpılarak Ankara' daki 5 yıldızlı konaklama işletmelerinde çalışan işgören sayısı tahmini 
olarak hesaplanmıştır. 5 yıldızlı Oteller için oda başına 1.18 kadar işgören ve yatak başına ise 0,59 oranında işgörene ihtiyaç vardır. Kültür ve Turizm Bakanlığının yayımladığı verilere göre Ankara ilinde 24 adet 5 yıldızlı konaklama işletmesi bulunmaktadır. Tablo' da bulunan bu otellerin booking.com aracılığıyla ulaşılmış oda sayıları bulunmaktadır.

Tablo 1. Ankara'da Bulunan 5 Yıldızlı Konaklama İşletmeleri ve Oda Sayıları

\begin{tabular}{ll}
\hline Ankara İlinde Bulunan 5 Yıldızh Konaklama İşletmeleri & Oda Sayları \\
\hline Anadolu Hotels Esenboğa Thermal & 354 \\
\hline Latanya Ankara & 291 \\
\hline Büyük Sürmeli Oteli & 205 \\
\hline Hotel Ankara Altınel & 172 \\
\hline Hotel İçkale & 122 \\
\hline Hotel Bilkent & 235 \\
\hline Ankara Hiltonsa Oteli & 309 \\
\hline Aktif Metropolitan & 96 \\
\hline Swıss Otel Ankara & 150 \\
\hline Jw Marrıott Ankara & 413 \\
\hline Rixos Grand Ankara & 215 \\
\hline Holıday Inn Ankara Çukurambar & 140 \\
\hline Bera Ankara & 209 \\
\hline Ataköșk Hotel & 63 \\
\hline Sheraton Lugal A Luxury Collectıon Hotel \& Conventıon Center & 311 \\
\hline Grannos Thermal Hotel\&Conventıon Center & 212 \\
\hline Esenboğa Airport Hotel & 120 \\
\hline Swıss Internatıonal Kızılcahamam & 588 \\
\hline Çam Thermal Resort \& Spa Conventıon Center & 256 \\
\hline Wyndham Ankara & 138 \\
\hline Crowne Plaza Ankara & 263 \\
\hline Ankara Varan / Mövenpick Otel & 176 \\
\hline Hilton Garden Inn Ankara & 176 \\
\hline Anadolu Hotels Downtown Ankara & 250 \\
\hline TOPLAM & $\mathbf{5 4 6 4}$ \\
\hline &
\end{tabular}

Tablo'da gösterildiği gibi Ankara'da faaliyet gösteren 5 yıldızlı konaklama işletmelerinin toplam oda sayısı 5464 olarak belirlenmiştir. Ankara'daki 5 yıldızlı konaklama işletmelerinde çalışan tahmini işgören sayısı 1.18 x 5.464= 6.447 olarak hesaplanmıştır. Örneklemin tespit edilmesinde kullanılan formül aşağıda gösterilmiştir (Aktuna, 2016:53).

$$
n=\frac{N \cdot z^{2} \cdot p \cdot q}{N \cdot d^{2}+z^{2} \cdot p \cdot q}
$$

\footnotetext{
N: yığındaki birey sayısı

n: örneklemdeki birey sayısı

z: istenilen güvenirlik düzeyi için standart normal dağılım tablo değeri
} 


\section{d: duyarlılık}

p: yığında istenilen özelliği taşıyan bireylerin oranı $(\mathrm{p}+\mathrm{q}=1)$

q: $1-\mathrm{p}$

$$
n=\frac{6447 \cdot(1,96)^{2} \cdot(0,5) \cdot(0,5)}{6447 \cdot(0,05)^{2}+(1,96)^{2} \cdot(0,5) \cdot(0,5)}
$$

Bu işleme göre örneklem sayısı 362 olarak hesaplanmıştır. Toplam 500 anket formu, konaklama işletmelerinde çalışan işgörenlere iletilmiştir. Bu anketlerden 410 tanesi geri dönmüştür. Bunlardan 19 tanesi geçersiz sayılmıştır. Geçersiz sayılan anketlerin değerlendirme dışı bırakılma sebebi araştırma için önemli olan ifadelerin eksik veya aynı şıkların birden fazla işaretlenmesinden kaynaklanmıştır. Araştırma kapsamında geçerli sayılan toplam 390 adet anket analize tabi tutulmuştur.

İşgörenlerin mutluluk düzeyleri, iş tatminleri ve çalışma performansları arasındaki ilişkiyi saptamaya yönelik anket uygulanmıştır. Veri toplama aracı dört bölümden oluşmaktadır. Birinci bölümde araştırmaya katılan işgörenlerın demografik özellikleri, ikinci bölümde işgörenlerin mutluluk düzeylerini ölçen Oxford mutluluk ölçeği, üçüncü bölümde işgörenlerin performanslarını ölçmeye yönelik; işgören performans ölçeği, dördüncü bölümde ise işgörenlerin iş tatminlerini ölçen Minnesota iş tatmin ölçeği kullanılmıştır. Anket formunda yer alan ifadelere katılımcılar ne derecede katıldıklarını belirtmek için 5'li likert ölçeği kullanılmıştır. Buna göre ifadeler, “Hiç Katılmıyorum (1), “Çoğunlukla Katılmıyorum (2)", "Biraz Katılıyorum (3), "Katılıyorum (4)", "Çoğunlukla Katıllyorum (5)" olarak belirtilmiştir. Anketin güvenirlilik düzeyini saptamak amacıyla cronbach alfa güvenirlilik testi kullanılmıştır. İşgören mutluluk düzeyi ölçeğinin genel güvenirlik değeri cronbach alpfa katsayısı; 0,87, iş tatmini ölçeğinin cronbach alpha katsayısı; 0,92, işgören performansı ölçeğinin güvenilirlik değeri cronbach alpha katsayısı; 0,73, bulunmuştur. Özdamar'a göre (2002:673) güvenirlilik katsayısı; $0.60 \mathrm{a}<0.80$ ise ölçek oldukça güvenilirdir. $0.80 \mathrm{a}<1.00$ ise ölçek yüksek derecede güvenilir bir ölçektir. Araştırmada elde edilen veriler, araştırmanın amacı doğrultusunda çeşitli istatistiki analizler (frekans, t testi, One-Way ANOVA, Pearson Korelasyonu) kullanılarak veriler yorumlanmıştır.

\section{BULGULAR}

Araştırmada elde edilen bulguların analizi sonucunda frekans tabloları ve hipotez testlerine ilişkin analiz tabloları aşağıda gösterilmiştir.

Araştırmaya katılan örneklem grubunun \%3,1'ini 20 yaş ve altındaki kişiler oluştururken, \%16,2' sini 21-25 yaş arası kişiler, \%24,6' 'sını 26-30 yaş arası kişiler, \%26.02' sini 31-35 yaş arası kişiler, \%19,5'ini 3640 yaşları arasındaki kişiler ve \%10,5'ini 41 yaş ve üzerindeki kişiler oluşturmaktadır. Yüzde ve frekans tablosuna göre araştırmaya katılan turizm işgörenlerinin büyük çoğunluğunu 31 ve 35 yaş arasındaki işgörenler oluşturmaktadır. Araştırmaya katılan işgörenlerin \%35,1'i Kadın ve \%64,9'u erkektir. Örneklem grubunun çoğunluğunu erkekler oluşturmaktadır. Örneklem grubundaki işgörenlerin yüzde ve frekans dağılımlarına göre; işgörenlerin \%44,4'ü evli kişilerden oluşmaktadır. Araştırmaya katılan örneklem grubunun sektör yılı değişkenine göre frekans ve yüzde dağıllmları tablo 6-4'te gösterilmiştir. Tablodan da anlaşılacağı üzere \%9,2'lik bir oranla 1 yıl ve altında işgörenlerin olduğu, \%33,6 ile 2 yıl ve 5 yıl arasında işgörenlerin olduğu, \%35,9 ile 6 ile 10 yıl arasında işgörenlerin olduğu, \%11,8'lik oran ile 11-15 yıl arasında işgörenlerin olduğu, \%9,5'lik oran ile 16 yıl ve üzerinde işgörenlerin olduğu anlaşılmaktadır. Diğer yanan araştırma örnekleminin çoğunluğu \%69,4'lük bir oran ile 2-5 yıl ile 6-10 yıl arasında olduğu anlaşılmaktadır. Araştırmaya katılan işgörenlerin işletme yılı değişkenine göre yüzde frekans tablosu yukarıda gösterilmiştir. Tabloya göre $\% 39,2^{\prime} l i k$ bir oran ile 1 yıl ve altında işgörenlerin olduğu, \%40,5 ile 2 yıl ile 5 yıl arasında işgörenların olduğu, \%15,4'lük oran ile 6 yıl ve 10 
yıl arasında işgörenların olduğu, \%3,1 ile 11 yıl ve 15 yıl arasında işgörenlerin olduğu ve \%1,8’lik oran ile 16 yıl ve üzerinde işgörenlerin olduğu görülmektedir.

Tablo 2. Araştırmaya Katılan İşgörenlerin Demografik Değişkenlere Göre Dağılımı

\begin{tabular}{|c|c|c|}
\hline Yaş & Frekans & Yüzde \\
\hline 20 Yaş ve Altı & 12 & 3,1 \\
\hline 21-25 Yaş & 63 & 16,2 \\
\hline 26-30 Yaş & 96 & 24,6 \\
\hline 31-35 Yaş & 102 & 26,02 \\
\hline $36-40$ Yaş & 76 & 19,5 \\
\hline 41 Yaş ve Üzeri & 41 & 10,5 \\
\hline Toplam & 390 & 100,0 \\
\hline Cinsiyet & Frekans & Yüzde \\
\hline Kadın & 137 & 35,1 \\
\hline Erkek & 253 & 64,9 \\
\hline Toplam & 390 & 100,0 \\
\hline Medeni Durum & Frekans & Yüzde \\
\hline Evli & 173 & 44,4 \\
\hline Bekar & 212 & 54,4 \\
\hline Toplam & 390 & 100,0 \\
\hline Sektördeki çalışma yılı & Frekans & Yüzde \\
\hline $0-1 Y_{1}$ & 36 & 9,2 \\
\hline $2-5 Y_{11}$ & 131 & 33,6 \\
\hline 6-10 Y1l & 140 & 35,9 \\
\hline $11-15 Y_{11}$ & 46 & 11,8 \\
\hline 16 Yil ve Üzeri & 37 & 9,5 \\
\hline Toplam & 390 & 100,0 \\
\hline İşletmedeki çalışma yılı & Frekans & Yüzde \\
\hline $0-1 Y_{11}$ & 153 & 39,2 \\
\hline $2-5 Y_{11}$ & 158 & 40,5 \\
\hline 6-10 Y 11 & 60 & 15,4 \\
\hline $11-15 Y_{11}$ & 12 & 3,1 \\
\hline 16 Yil ve Üzeri & 7 & 1,8 \\
\hline Toplam & 390 & 100,0 \\
\hline Eğitim Durumu & Frekans & Yüzde \\
\hline İlköğretim & 38 & 9,7 \\
\hline Lise & 170 & 43,6 \\
\hline Üniversite & 182 & 46,7 \\
\hline Toplam & 390 & 100,0 \\
\hline Pozisyon & Frekans & Yüzde \\
\hline İşgören & 303 & 77,7 \\
\hline Yönetici & 87 & 22,3 \\
\hline Toplam & 390 & 100,0 \\
\hline Departman & Frekans & Yüzde \\
\hline Mutfak & 21 & 5,4 \\
\hline Yiyecek ve içecek & 64 & 16,4 \\
\hline Ön büro & 155 & 39,7 \\
\hline Banket & 30 & 7,7 \\
\hline Kayıp Önleme & 51 & 13,1 \\
\hline İnsan kaynakları & 15 & 3,8 \\
\hline Satış ve pazarlama & 36 & 9,2 \\
\hline Teknik servis & 18 & 4,6 \\
\hline Toplam & 390 & 100,0 \\
\hline
\end{tabular}


Diğer yandan araştırmaya katılan örneklem grubunun çoğunluğunu \%40,5 ile 2 yıl ve 5 yıl arasındaki işgörenler oluşturmaktadır. Örneklem grubunu oluşturan işgörenlerin eğitim değişkenine göre yüzde ve frekans tablosuna bakıldığında \%9,7'lik bir oranla ilköğretim mezunu işgörenlerin olduğu, \%43,6'llk bir oranla lise mezunu işgörenlerin olduğu ve \%46,7 ile üniversite mezunu işgörenlerin olduğu görülmektedir. Tabloya göre örnekleme katılan grubun azınlığını ilköğretim mezunu işgörenler oluşturmaktadır. Araştırmaya katılan örneklem grubunun pozisyon değişkenine göre yüzde ve frekans dağılımları tablo $7^{\prime}$ de gösterilmiştir. Tablodan da anlaşılacağı üzerine $\% 77,7^{\prime}$ lik bir oran ile örneklem grubunun işgörenlerden oluştuğu, \%22,3'lük oran ile yöneticilerden oluştuğu görülmektedir. Ankete katılan işgörenlerin çalıştıkları departmana göre yüzde ve frekans dağılımları tablo $8^{\prime}$ de gösterilmiştir. Tablodan da anlaşılacağı üzere örneklem grubunu oluşturan işgörenlerin \%5,4'lük bir kısmı mutfak departmanında, \%16,4'lük bir kısmı yiyecek ve içecek departmanında, \%39,7'lik bir kısmı ön büro departmanında, \%7,7'lik bir kısmı banket departmanında, \%13,1'lik bir kısmı kayıp önleme (güvenlik) departmanında, \%3,8'lik bir kısmı insan kaynakları departmanında, \%9,2'lik bir kısmı satış ve pazarlama departmanında ve \%4,6'lık bir kısmı ise teknik servis departmanında çalışmaktadır. Diğer yandan örnekleme katılan araştırma grubunun büyük çoğunluğunu \%56,1'lik oran ile yiyecek ve içecek departmanı işgörenleri ile ön büro işgörenleri oluşturmaktadır.

Tablo 3. İşgörenlerin Mutluluk Düzeyleri ile İş Tatmin ve Performans Düzeyleri Arasındaki Korelasyon Analizi

\begin{tabular}{|l|l|c|c|c|}
\hline \multicolumn{2}{|l|}{} & İşören mutluluğu & İş tatmini & İşgören performans \\
\hline \multirow{3}{*}{ İşgören mutluluğu } & $\mathrm{r}$ & 1 &, $361^{* *}$ &, $415^{* *}$ \\
\cline { 2 - 5 } & $\mathrm{p}$ & &, 000 &, 000 \\
\cline { 2 - 5 } & $\mathrm{N}$ & 390 & 390 & 390 \\
\hline \multirow{3}{*}{ İş tatmini } & $\mathrm{r}$ &, $361^{* *}$ & 1 &, $223^{* *}$ \\
\cline { 2 - 5 } & $\mathrm{p}$ &, 000 & & 3900 \\
\cline { 2 - 5 } & $\mathrm{N}$ & 390 &, $223^{* *}$ & 1 \\
\hline \multirow{2}{*}{ İşgören performansı } & $\mathrm{r}$ &, $415^{* *}$ &, 000 & 390 \\
\cline { 2 - 5 } & $\mathrm{p}$ &, 000 & 390 & \\
\cline { 2 - 5 } & $\mathrm{N}$ & 390 &
\end{tabular}

Hipotez 1: İşgörenlerin mutluluk düzeyleri ile iş tatminleri arasında ilişki vardır. Araştırmaya katılan örneklem grubunun mutluluk düzeyi ile iş tatmini arasındaki ilişkiye bakılmış olup 0,01 önem düzeyinde anlamlı bir ilişki tespit edilmiştir ve ilişkinin şiddeti $r=.361$ olduğu görülmektedir. Diğer bir ifade ile turizm işgörenlerinin mutluluk düzeyleri ile iş tatminleri arasında dikkate değer bir ilişki söz konusudur. Yapılan analizde bulunan korelasyon katsayısının anlamlılığının oldukça yüksek olduğu $(\mathrm{p}=0,000)$ tespit edilerek hipotez 1 yeterli kanıtla desteklenmiştir.

Hipotez 2: İşgörenlerin iş tatminleri ile çalışma performansları arasında ilişki vardır. Örneklem grubunun iş tatmini ile çalışma performansları arasındaki ilişkiye bakılmış olup 0,01 önlem düzeyinde anlamlı bir ilişki tespit edilmiştir ve ilişkinin şiddeti $r=, 223$ olduğu görülmektedir. Turizm işgörenlerinin iş tatminleri ile çalışma performansları arasında dikkate değer bir ilişki bulunmaktadır. Hipotez 2 yeterli kanıtla desteklenmiştir.

Hipotez 3: İşgörenlerin mutluluk düzeyleri ile çalışma performansları arsında ilişki vardır. Araştırmaya katılan örneklem grubunun mutluluk düzeyi ile çalışma performansı arasındaki ilişkiye bakılmış olup 0,01 önem düzeyinde anlamlı bir ilişki tespit edilmiştir. İlişkinin şiddeti $r=.415$ olduğu görülmektedir. Yani turizm işgörenlerinin mutluluk düzeyi ile çalışma performansları arasında önemli bir ilişki tespit edilmiştir. Hipotez 3 yeterli kanıtla desteklenmiştir. 
Tablo 4. İşgörenlerinin Mutluluk Düzeyi, İş Tatmini ve Çalışma Performansı Düzeylerinin Yaş Değişkeni Açısından Farklılaşması

\begin{tabular}{|c|c|c|c|c|c|c|}
\hline & Yaş Gurupları & $\mathrm{N}$ & $\bar{x}$ & s.s. & $t$ & $p$ \\
\hline \multirow[t]{7}{*}{ Mutluluk Düzeyi } & 20 yaş ve altı & 12 & 3,2040 & ,49720 & \multirow[t]{7}{*}{1,297} & \multirow[t]{7}{*}{264} \\
\hline & $20-25$ yaş arası & 63 & 3,2129 & ,42556 & & \\
\hline & $26-30$ yaş arası & 96 & 3,2367 & ,33311 & & \\
\hline & 31-35 yaş arası & 102 & 3,1504 & 36647 & & \\
\hline & $36-40$ yaş arası & 76 & 3,2641 & ,34632 & & \\
\hline & 41 yaş ve üzeri & 41 & 3,3212 & ,56795 & & \\
\hline & Toplam & 390 & 3,2225 & ,39588 & & \\
\hline \multirow[t]{7}{*}{ İş Tatmini } & 20 yaş ve altı & 12 & 2,8667 & ,81529 & \multirow[t]{7}{*}{3,437} & \multirow[t]{7}{*}{,005 } \\
\hline & $20-25$ yaş arası & 63 & 3,2571 & 62060 & & \\
\hline & $26-30$ yaş arası & 96 & 3,2271 & ,75365 & & \\
\hline & 31-35 yaş arası & 102 & 2,9485 & ,67452 & & \\
\hline & $36-40$ yaş arası & 76 & 3,2125 & ,74297 & & \\
\hline & 41 yaş ve üzeri & 41 & 3,3939 & ,86820 & & \\
\hline & Toplam & 390 & 3,1627 & 73775 & & \\
\hline \multirow{7}{*}{$\begin{array}{l}\text { Çalışma } \\
\text { Performansı }\end{array}$} & 20 yaş ve altı & 12 & 4,3958 & 1,011387 & \multirow[t]{7}{*}{1,052} & \multirow[t]{7}{*}{,387 } \\
\hline & $21-25$ yaş arası & 63 & 4,1468 & ,71227 & & \\
\hline & $26-30$ yaş arası & 96 & 4,0755 & ,73639 & & \\
\hline & 31-35 yaş arası & 102 & 4,0049 & 85523 & & \\
\hline & $36-40$ yaş arası & 76 & 4,1250 & ,68374 & & \\
\hline & 41 yaş ve üzeri & 41 & 4,2378 & ,60454 & & \\
\hline & Toplam & 390 & 4,1051 & ,75342 & & \\
\hline
\end{tabular}

Hipotez 4a: Yaş değişkeni açısından; işgörenlerin Mutluluk Düzeylerinde Farklılaşma Vardır. Araştırmaya katılan örneklem grubunun yaş değişkenine göre mutluluk düzeyi algısında bir farklılaşma olup olmadığı araştırılmış, mutluluk düzeyi ile yaş arasında anlamlı bir farklılaşma tespit edilememiştir ( $p>05$ ). Hipotez 4a. yeterli kanttla desteklenememiştir. Hipotez 4b: Yaş değişkeni açısından işgörenlerin iş tatmini algılarında farklılaşma vardır. Araştırmaya katılan örneklem grubunun yaş değişkenine göre iş tatmini algısında bir farklılaşma tespit edilmiştir ( $\mathrm{p}<.05)$. Hipotez $4 \mathrm{~b}$ yeterli kanıtla desteklenmiştir. Benzer biçimde Toker (2007:103) çalışmasında demografik değişkenlerden çalışanların yaşının iş tatmini düzeylerinde farklılık gösterdiği saptanmıştır. Bu çerçevede, konaklama işletmeleri çalışanlarının yaşları ilerledikçe iş tatminlerinde artış görüldügü ifade edilebilir. Literatürdeki araştırmalar da yaş ile tatmin arasında genellikle olumlu bir ilişki olduğunu göstermekte ve araştırma sonuçlarını desteklemektedir. Çalışanların yaşları ilerledikçe işlerinde daha çok tatmin oldukları görülmektedir. Bunun nedeni ise, ilerleyen yaşla birlikte, deneyim nedeniyle uyumun artması olabilir. Diğer yandan, daha genç çalışanların yükselme ve diğer iş koşullarına yönelik aşırı beklentilere sahip olmaları nedeniyle, işe yeni başladıklarında tatminsiz olma olasılıkları oldukça yüksektir. Hipotez 4c: Yaş değişkeni açısından işgörenlerin performans algılarında farklılaşma vardır. Araştırmaya kayılan örneklem grubunun yaş değişkenine göre performans algısı düzeylerinde farklılaşma olup olmadığı araştırılmış, istatistiksel olarak yaş değişkeni ile performans arasında anlamlı bir farklılaşma tespit edilememiştir (p>.05). Hipotez 4c yeterli kanıtla desteklenememiştir. 
Tablo 5. Cinsiyet Değişkeni Açısından Mutluluk Düzeyi, İş Tatmini ve Çalışma Performansı Düzeylerinin Farklılaşması

\begin{tabular}{|c|c|c|c|c|c|c|}
\hline & Cinsiyet & $\mathrm{N}$ & $\bar{x}$ & s.s. & $\mathrm{t}$ & $\mathrm{p}$ \\
\hline \multirow{2}{*}{$\begin{array}{l}\text { Mutluluk } \\
\text { Düzeyi }\end{array}$} & Kadın & 137 & 3,2124 & ,33210 & \multirow[t]{2}{*}{,- 368} & \multirow[t]{2}{*}{,713 } \\
\hline & Erkek & 253 & 3,2279 & ,42698 & & \\
\hline \multirow[t]{2}{*}{ İş Tatmini } & Kadın & 137 & 3,0197 & ,69572 & \multirow[t]{2}{*}{$-2,842$} & \multirow[t]{2}{*}{,005 } \\
\hline & Erkek & 253 & 3,2401 & 74955 & & \\
\hline \multirow{2}{*}{$\begin{array}{l}\text { İşgören } \\
\text { Performans1 }\end{array}$} & Kadın & 137 & 4,0584 & ,78196 & \multirow[t]{2}{*}{,- 901} & \multirow[t]{2}{*}{ 368 } \\
\hline & Erkek & 253 & 4,1304 & ,73785 & & \\
\hline
\end{tabular}

Hipotez 5a: Cinsiyet değişkeni açısından; işgörenlerin mutluluk düzeyleri arasında farklılaşma vardır. Araştırmaya katılan örneklem grubunun cinsiyet değişkenine göre mutluluk düzeylerinde bir farklılaşma olup olmadığı araştırılmış, istatistiksel olarak cinsiyet değişkeni ile mutluluk düzeyleri arasında anlamlı bir farklılaşma tespit edilememiştir ( $>$ >05). Hipotez 5a yeterli kanıtla desteklenememiştir. Hipotez 5b.: Cinsiyet değişkeni açısından; işgörenlerin iş tatmin düzeyleri arasında farklılaşma vardır. Cinsiyet değişkeni açısından turizm işgörenlerinin iş tatmin düzeylerinde farklılaşma tespit edilmiştir $(\mathrm{p}<.05)$. Kadınların iş tatmin algıları $(3,01)$ erkeklerin iş tatmin algılarından $(3,24)$ daha düşüktür. Kadınların hizmet sektöründe daha zor şartlarda çalışıp terfi imkanlarının daha düşük olmasından dolayı turizmde işgören kadınların iş tatmin seviyeleri daha düşük olduğu görülmektedir. Hipotez $5 b$ yeterli kanıtla desteklenmiştir. Diğer yandan Aşan ve Erenler'in (2008:212) yaptığı çalışmasında işten duyulan genel memnuniyet ve yaşamdan aldıkları doyum ile cinsiyet arasında anlamlı bir fark bulunmamıştır.

Hipotez 5c: Cinsiyet değişkeni açısından; işgörenlerin performans düzeyleri arasında farklılaşma vardır. Araştırmaya katılan örneklem grubunun cinsiyet değişkenine göre performans düzeylerinde farklılaşma olup olmadığı araştırılmış, istatistiksel olarak cinsiyet değişkenine göre performans düzeylerinde anlamlı bir farklılaşma tespit edilememiştir ( $\mathrm{p}>.05)$. Hipotez $5 c$ yeterli kanıtla desteklenememiştir.

Tablo 0. Medeni Durum Değişkeni Açısından İşgörenlerin Mutluluk Düzeyi, İş Tatmini ve Çalışma Performansı Düzeylerinin Farklılaşması

\begin{tabular}{|l|l|l|l|l|l|l|}
\hline & $\begin{array}{l}\text { Medeni } \\
\text { Durum }\end{array}$ & $\mathrm{N}$ & $\overline{\mathrm{x}}$ & $\mathrm{s}$ & $\mathrm{t}$ & $\mathrm{p}$ \\
\hline \multirow{2}{*}{ Mutluluk Düzeyi } & Evli & 173 & 3,2458 &, 45304 & \multirow{2}{*}{, 915} & \multirow{2}{*}{, 361} \\
\cline { 2 - 7 } & Bekar & 212 & 3,2085 &, 34484 & & \\
\hline \multirow{2}{*}{ İş Tatmini } & Evli & 173 & 3,2367 &, 74928 & 1,724 & \multirow{2}{*}{086} \\
\cline { 2 - 5 } & Bekar & 212 & 3,1064 &, 72876 & & \\
\hline \multirow{2}{*}{$\begin{array}{l}\text { İsören } \\
\text { Performans1 }\end{array}$} & Evli & 173 & 4,1590 &, 72137 & 1,245 &, 214 \\
\cline { 2 - 5 } & Bekar & 212 & 4,0625 &, 78375 & & \\
\hline
\end{tabular}

Hipotez 6a: Medeni durum değişkeni açısından; işgörenlerin mutluluk düzeyleri arasında farklılaşma vardır. Araştırmaya katılan örneklem grubunun medeni durum değişkenine göre mutluluk düzeylerinde bir farklılaşma olup olmadığı araştııılmış, istatistiksel olarak medeni durum değişkenine göre mutluluk düzeylerinde anlamlı bir farklılaşma tespit edilememiştir(p>.05). Hipotez 6a yeterli kanıtla desteklenememiştir. Hipotez 6b: Medeni durum değişkeni açısından; işgörenlerin iş tatmin düzeyleri arasında farklılaşma vardır. Araştırmaya katılan örneklem grubunun medeni durum değişkenine göre iş tatmin düzeylerinde bir farklılaşma olup olmadığı araştırılmış, istatistiksel olarak 
medeni durum değişkenine göre iş tatmini düzeylerinde anlamlı bir farklılaşma tespit edilememiştir (p>.05). Hipotez $6 b$ yeterli kanıtla desteklenememiştir. Buna karşın Ünsar ve arkadaşlarının yaptığ1 araştırmada çalışanların medeni durumları ile iş tatmini boyutları arasındaki ilişkiler analiz edilmiştir (Ünsar vd., 2010:58). Analiz sonuçlarına göre işin ekonomik koşullarından duyulan tatmin ve işten genel memnuniyet, çalışanların medeni durumlarından etkilenmektedir. Evli olan çalışanlarda iş tatmini ekonomik ve genel memnuniyet düzeyi yönlerinden evli olmayanlara göre (bekar, dul) farklı çıkmıştır. Evli çalışanlara sorulan sorular arasında eşlerinin de çalışıp çalışmadığı sorulmuş ve \%90' nın eşinin de çalıştığı cevabı alınmıştır. Evli bir çalışanın eşinin de çalışıyor olması şu an işinden elde ettiği ekonomik tatminin artmasına etki etmektedir. Hipotez 6c: Medeni durum değişkeni açısından; işgörenlerin performans düzeyleri arasında farklılaşma vardır. Araştırmaya katılan örneklem grubunun medeni durum değişkenine göre çalışma performansı düzeyinde bir farklılaşma olup olmadığı araştırılmış, istatistiksel olarak medeni durum değişkenine göre çalışma performansında anlamlı bir farklılaşma tespit edilememiştir ( $p>.05)$. Hipotez 6c yeterli kanıtla desteklenememiştir.

Tablo 7. Sektördeki Çalışma Yılı Değişkeni Açısından İşgörenlerin Mutluluk Düzeyi, İş Tatmini ve Çalışma Performansı Düzeylerinin Farklılaşması

\begin{tabular}{|c|c|c|c|c|c|c|}
\hline $\begin{array}{l}\text { Sektördeki } \\
\text { Çalışma Yılı }\end{array}$ & & $\mathrm{N}$ & $\bar{x}$ & s.s. & $\mathrm{F}$ & $\mathrm{p}$ \\
\hline \multirow{6}{*}{$\begin{array}{l}\text { Mutluluk } \\
\text { Düzeyi }\end{array}$} & 0-1 Yil Aras1 & 36 & 3,1705 & 49450 & \multirow[t]{6}{*}{,727 } & \multirow[t]{6}{*}{,574 } \\
\hline & 2-5 Yil Arası & 131 & 3,1922 & ,40477 & & \\
\hline & 6-10 Y1l Aras1 & 140 & 3,2387 & ,37948 & & \\
\hline & 11-15 Y1l Arası & 46 & 3,2436 & ,35779 & & \\
\hline & 16 Y1l ve Üzeri & 37 & 3,2926 & ,36787 & & \\
\hline & Toplam & 390 & 3,2225 & ,39588 & & \\
\hline \multirow[t]{6}{*}{ İ̀s Tatmini } & 0-1 Yıl Arası & 36 & 3,2222 & ,70290 & \multirow[t]{6}{*}{2,973} & \multirow[t]{6}{*}{,019 } \\
\hline & 2-5 Yil Aras1 & 131 & 3,0496 & ,73969 & & \\
\hline & 6-10 Y1l Arası & 140 & 3,1232 & ,75580 & & \\
\hline & 11-15 Y1l Aras1 & 46 & 3,3250 & ,55805 & & \\
\hline & 16 Yll ve Üzeri & 37 & 3,4527 & 80872 & & \\
\hline & Toplam & 390 & 3,1627 & ,73775 & & \\
\hline \multirow{6}{*}{$\begin{array}{l}\text { Çalışma } \\
\text { performansı }\end{array}$} & 0-1 Yıl Arası & 36 & 4,0556 & ,81747 & \multirow[t]{6}{*}{837} & \multirow[t]{6}{*}{,502 } \\
\hline & 2-5 Yil Arasi & 131 & 4,0248 & ,84401 & & \\
\hline & 6-10 Y1l Aras1 & 140 & 4,1839 & 69467 & & \\
\hline & 11-15 Y1l Aras1 & 46 & 4,0924 & ,66533 & & \\
\hline & $16 Y_{11}$ ve Üzeri & 37 & 4,1554 & ,66498 & & \\
\hline & Toplam & 390 & 4,1051 & ,75342 & & \\
\hline
\end{tabular}

Hipotez 7a: Sektördeki çalışma yılı değişkeni açısından; işgörenlerin mutluluk düzeyi algılarında farklılık vardır. İşgörenlerin mutluluk algılarında sektördeki çalışma yılı değişkenine göre farklılaşma durumunu ölçmek amacıyla one-way anova testi yapılmıştır. Analiz sonuçlarına göre mutluluk algı düzeylerinde anlamlı bir farklılaşma görülmemiştir. Hipotez 7a yeterli kanıtla desteklenememiştir. Hipotez $7 \mathrm{~b}$ : Sektördeki çalışma yılı değişkeni açısından, işgörenlerin iş tatmini düzeylerinde farklılık vardır. İşgörenlerin iş tatmini düzeylerindeki farklılaşmayı ölçmek amacıyla yapılan anova testi sonucunda anlamlı bir farklılık gözlenmiştir. Araştırma verilerine göre sektördeki çalışma yılı 16 ve üzerinde olan işgörenlerinin tatmini algı düzeyleri $(\bar{x}=3,45)$ sektördeki çalışma yılı 16 yıldan daha az olan işgörenlere göre daha yüksektir. Hipotez $7 \mathrm{~b}$ yeterli kanıtla desteklenmiştir. Hipotez 7c.: Sektördeki çalışma yılı değişkeni açısından işgörenlerin çalışma performansı düzeylerinde farklılık vardır. 
İşgörenlerin çalışma performansı algılarındaki farklılaşmayı ölçmek amacıyla yapılan anova testi sonucunda anlamlı bir farklılık gözlenmemiştir. Hipotez 7c yeterli kanıtla desteklenememiştir

Tablo 8. İşletmedeki Çalışma Yılı Değişkeni Açısından İşgörenlerin Mutluluk Düzeyi, İş Tatmini ve Çalışma Performansı Düzeylerinin Farklılaşması

\begin{tabular}{|c|c|c|c|c|c|c|}
\hline & $\begin{array}{l}\text { İşletmedeki Çalışma } \\
\text { Yılı }\end{array}$ & $\mathrm{N}$ & $\bar{x}$ & s.s. & $\mathrm{F}$ & $\mathrm{p}$ \\
\hline \multirow{6}{*}{$\begin{array}{l}\text { Mutluluk } \\
\text { Düzeyi }\end{array}$} & $0-1$ Yil Arası & 153 & 3,1898 & ,37760 & \multirow[t]{6}{*}{,543 } & \multirow[t]{6}{*}{704} \\
\hline & 2-5 Yil Arası & 158 & 3,2436 & ,40993 & & \\
\hline & 6-10 Yil Aras1 & 60 & 3,2603 & ,43323 & & \\
\hline & 11-15 Y1l Aras1 & 12 & 3,1810 & ,26756 & & \\
\hline & 16 Y1l ve Üzeri & 7 & 3,2069 & ,34310 & & \\
\hline & Toplam & 390 & 3,2225 & ,39588 & & \\
\hline \multirow[t]{6}{*}{ İş Tatmini } & 0-1 Y1l Arası & 153 & 3,1065 & ,69253 & \multirow[t]{6}{*}{4,233} & \multirow[t]{6}{*}{,002 } \\
\hline & 2-5 Y1l Arası & 158 & 3,0759 & ,76610 & & \\
\hline & 6-10 Y1l Arası & 60 & 3,4892 & ,69460 & & \\
\hline & 11-15 Y1l Aras1 & 12 & 3,4250 & ,48967 & & \\
\hline & 16 Y1l ve Üzeri & 7 & 3,1000 & 1,05357 & & \\
\hline & Toplam & 390 & 3,1627 & ,73775 & & \\
\hline \multirow{6}{*}{$\begin{array}{l}\text { Çalışma } \\
\text { Performans }\end{array}$} & 0-1 Yıl Arası & 153 & 4,0719 & ,75037 & \multirow[t]{6}{*}{,478 } & \multirow[t]{6}{*}{,752 } \\
\hline & 2-5 Y1l Arasi & 158 & 4,1582 & ,76464 & & \\
\hline & 6-10 Y1l Aras1 & 60 & 4,1000 & ,78005 & & \\
\hline & 11-15 Y1l Aras1 & 12 & 3,9375 & 61353 & & \\
\hline & $16 Y_{11}$ ve Üzeri & 7 & 3,9643 & ,61962 & & \\
\hline & Toplam & 390 & 4,1051 & ,75342 & & \\
\hline
\end{tabular}

Hipotez 8a: İşletmedeki çalışma yılı değişkeni açısından; işgörenlerin mutluluk düzeyinde farklılık vardır. İşgörenlerin mutluluk algılarında işletmedeki çalışma yılı değişkenine göre farklılaşma durumunu ölçmek amacıyla one-way anova testi yapılmıştır. Analiz sonuçlarına göre mutluluk algı düzeylerinde anlamlı bir farklılaşma görülmemiştir. Hipotez 8a yeterli kanıtla desteklenememiştir. Hipotez 8b: İşletmedeki çalışma yılı değişkeni açısından turizm işgörenlerinin iş tatmini düzeylerinde farklılık vardır. İşgörenlerin iş tatmini algılarındaki farklılaşmayı ölçmek amacıyla yapılan anova testi sonucunda anlamlı bir farklılık gözlenmiştir. Araştırma verilerine göre işletmedeki çalışma yılı 6 ve 10 yıl arasında olan işgörenlerin iş tatmini algı düzeyleri $(\bar{x}=3,48)$ sektördeki çalışma yılı $0-1$ yıl arası olan işgörenlerden, 2-5 yıl arası olan işgörenlerden, 11-15 yıl arası olan işgörenlerden ve işletmedeki çalışma yılı 16 ve üzeri olan işgörenlerden daha yüksektir. Hipotez $8 \mathrm{~b}$ yeterli kanitla desteklenmiştir. Tor (2011:112) tarafından yapılan bir çalışmada, iş tatmininde hizmet yılı grupları içinde en fazla iş tatmin düzeyinin farklılık göstermesi 6-10 hizmet yılında olduğu, iş doyumlarının ise birbirine en yakın grubun 11-15 hizmet yılı grubu olduğu görülmüştür. Bu sonuçlar ile bulunduğu görevde hizmet süresinin 5 yılın üzerine çıktığında iş doyumlarında azalma olduğu ortaya çıkmıştır. Hipotez 8c: İşletmedeki çalışma yılı değişkeni açısından turizm işgörenlerinin çalışma performans düzeylerinde farklılık vardır. İşgörenlerin çalışma performansındaki farklılaşmayı ölçmek amacıyla yapılan anova testi sonucunda anlamlı bir farklılık gözlenmemiştir. Hipotez 8c yeterli kanıtla desteklenememiştir. 
Tablo 9. Eğitim Değişkeni Açısından İşgörenlerin Mutluluk Düzeyi, İş Tatmini ve Çalışma Performansı Düzeylerinin Farklılaşması

\begin{tabular}{|c|c|c|c|c|c|c|}
\hline & Eğitim Durumu & $\mathrm{N}$ & $\bar{x}$ & s.s. & $\mathrm{F}$ & $\mathrm{p}$ \\
\hline \multirow[t]{4}{*}{ Mutluluk Düzeyi } & İlköğretim & 38 & 3.2024 & ,54600 & \multirow[t]{4}{*}{,089 } & \multirow[t]{4}{*}{ 915 } \\
\hline & Lise & 170 & 3.2304 & ,38425 & & \\
\hline & Üniversite & 182 & 3,2453 & 37130 & & \\
\hline & Toplam & 390 & 3,2225 & ,39588 & & \\
\hline \multirow[t]{4}{*}{ İş Tatmini } & İlköğretim & 38 & 3,1092 & ,98536 & \multirow[t]{4}{*}{2,169} & \multirow[t]{4}{*}{,116 } \\
\hline & Lise & 170 & 3,0862 & 65430 & & \\
\hline & Üniversite & 182 & 3,2453 & ,74738 & & \\
\hline & Toplam & 390 & 3,1627 & ,73775 & & \\
\hline \multirow{4}{*}{$\begin{array}{l}\text { Çalışma } \\
\text { performansı }\end{array}$} & İlköğretim & 38 & 3,9342 & ,98536 & \multirow[t]{4}{*}{1,267} & \multirow[t]{4}{*}{,283 } \\
\hline & Lise & 170 & 4,0985 & ,71610 & & \\
\hline & Üniversite & 182 & 4,1051 & ,75342 & & \\
\hline & Toplam & 390 & 4,1051 & ,75342 & & \\
\hline
\end{tabular}

Hipotez 9a: Eğitim değişkeni açısından; işgörenlerin mutluluk düzeylerinde farklılık vardır. İşgörenlerin mutluluk düzeylerinde işletmedeki eğitim değişkenine göre farklılaşma durumunu ölçmek amacıyla one-way anova testi yapılmıştır. Analiz sonuçlarına göre mutluluk algı düzeylerinde anlamlı bir farklılaşma görülmemiştir. Hipotez 9a yeterli kanıtla desteklenememiştir. Hipotez 9b: Eğitim değişkeni açısından işgörenlerin iş tatmin düzeylerinde farklılık vardır. İşgörenlerin iş tatmini düzeylerinde farklılaşmayı ölçmek amacıyla yapılan anova testi sonucunda anlamlı bir farklılık gözlenememiştir. Hipotez 9b yeterli kanıtla desteklenememiştir. Benzer çalışmalarda katılımcıların eğitim düzeylerine göre iş tatminlerinin değişip değişmediğini belirlenmeye çalışılmış, analiz sonucunda değişkenler arasında istatistiksel açıdan anlamlı bir farklılık olmadığı görülmüştür (Karaman, 2018:70). Hipotez 9c: Eğitim değişkeni açısından işgörenlerin çalışma performansı düzeylerinde farklılık vardır. İşgörenlerin çalışma performansı düzeylerindeki farklılaşmayı ölçmek amacıyla yapılan anova testi sonucunda anlamlı bir farklılık gözlenmemiştir. Hipotez 9c yeterli kanıtla desteklenememiştir.

Tablo 10. Yönetici Olup Olmama Değişkeni Açısından İşgörenlerin Mutluluk Düzeyi, İş Tatmini ve Çalışma Performansı Düzeylerinin Farklılaşması

\begin{tabular}{|c|c|c|c|c|c|c|}
\hline & Pozisyon & $\mathrm{N}$ & $\bar{x}$ & s.s. & $\mathrm{t}$ & $\mathrm{P}$ \\
\hline \multirow[t]{2}{*}{ Mutluluk Düzeyi } & İşgören & 303 & 3,2242 & ,41370 & \multirow[t]{2}{*}{ 152 } & \multirow[t]{2}{*}{879} \\
\hline & Yönetici & 84 & 3,2167 & ,33345 & & \\
\hline \multirow[t]{2}{*}{ İş Tatmini } & İşgören & 303 & 3,1025 & ,73302 & \multirow[t]{2}{*}{$-2,874$} & \multirow[t]{2}{*}{,004 } \\
\hline & Yönetici & 84 & 3,3613 & 72117 & & \\
\hline \multirow[t]{2}{*}{ İşgören Performansı } & İşgören & 303 & 4,0809 & ,76561 & \multirow[t]{2}{*}{$-1,540$} & \multirow[t]{2}{*}{, 124 } \\
\hline & Yönetici & 84 & 4,2232 & ,68878 & & \\
\hline
\end{tabular}

Hipotez 10a: Yönetici olup olmama değişkeni açısından işgörenlerin mutluluk düzeyinde farklılık vardır. İşgörenlerin mutluluk düzeyleri yönetici olup olmama değişkenine göre farklılaşma durumunu ölçmek amacıyla t testi yapılmıştır. Analiz sonuçlarına göre mutluluk algı düzeylerinde anlamlı bir farklılaşma görülmemiştir. Hipotez 10a yeterli kanıtla desteklenememiştir. Hipotez 10b: Yönetici olup olmama değişkeni açısından işgörenlerin iş tatmini düzeyinde farklılık vardır. İşgörenlerin iş tatmini 
düzeyinde farklılaşmayı ölçmek amacıyla yapılan $\mathrm{t}$ testi sonucunda anlamlı bir farklılık gözlenmiştir. Hipotez 10b yeterli kanıtla desteklenmiştir. Hipotez 10c: Yönetici olup olmama değişkeni açısından: işgörenlerin çalışma performansında farklılık vardır. İşgörenlerin çalışma performansı algılarındaki farklılaşmayı ölçmek amacıyla yapılan $t$ testi sonucunda anlamlı bir farklılık gözlenmemiştir. Hipotez 10c yeterli kanitla desteklenememiştir.

Tablo 11. Departman Değişkeni Açısından İşgörenlerin Mutluluk Düzeyi, İş Tatmini ve Çalışma Performansı Düzeylerinin Farklılaşması

\begin{tabular}{|c|c|c|c|c|c|c|}
\hline & Departman & $\mathrm{N}$ & $\bar{x}$ & s.s. & F & $p$ \\
\hline \multirow{9}{*}{$\begin{array}{l}\text { Mutluluk } \\
\text { Düzeyi }\end{array}$} & Mutfak & 21 & 3,2118 & ,44069 & \multirow[t]{9}{*}{,550 } & \multirow[t]{9}{*}{,797 } \\
\hline & Yiyecek ve İçecek & 64 & 3,2732 & ,48713 & & \\
\hline & Ön Büro & 155 & 3,2230 & ,37749 & & \\
\hline & Banket & 30 & 3,2230 & ,37749 & & \\
\hline & Kayıp Önleme & 51 & 3,1711 & ,26369 & & \\
\hline & İnsan Kaynakları & 15 & 3,2207 & , 15683 & & \\
\hline & Satış Pazarlama & 36 & 3,1456 & , 18323 & & \\
\hline & Teknik Servis & 18 & 3,2912 & , 18858 & & \\
\hline & Toplam & 390 & 3,2225 & ,39588 & & \\
\hline \multirow[t]{9}{*}{ İş Tatmini } & Mutfak & 21 & 3,3929 & ,80797 & \multirow[t]{9}{*}{2,073} & \multirow[t]{9}{*}{,046 } \\
\hline & Yiyecek ve İçecek & 64 & 3,2625 & ,79232 & & \\
\hline & Ön Büro & 155 & 3,0406 & 78884 & & \\
\hline & Banket & 30 & 3,4233 & 61961 & & \\
\hline & Kayıp Önleme & 51 & 3,0608 & ,41089 & & \\
\hline & İnsan Kaynakları & 15 & 3,4133 & ,56992 & & \\
\hline & Satış Pazarlama & 36 & 3,1500 & ,73183 & & \\
\hline & Teknik Servis & 18 & 3,2611 & ,86340 & & \\
\hline & Toplam & 390 & 3,1627 & ,73775 & & \\
\hline \multirow{9}{*}{$\begin{array}{l}\text { Çaışma } \\
\text { Performans }\end{array}$} & Mutfak & 21 & 3,9881 & 1,08822 & \multirow[t]{9}{*}{,348 } & \multirow[t]{9}{*}{,931 } \\
\hline & Yiyecek ve İçecek & 64 & 4,1445 & 83310 & & \\
\hline & Ön Büro & 155 & 4,1403 & 68796 & & \\
\hline & Banket & 30 & 4,1750 & ,88850 & & \\
\hline & Kayıp Önleme & 51 & 4,000 & ,71239 & & \\
\hline & İnsan Kaynakları & 15 & 4,0667 & ,60847 & & \\
\hline & Satış Pazarlama & 36 & 4,0556 & ,72975 & & \\
\hline & Teknik Servis & 18 & 4,1111 & ,64296 & & \\
\hline & Toplam & 390 & 4,1051 & ,75342 & & \\
\hline
\end{tabular}

Hipotez 11a: Departman değişkeni açısından; İşgörenlerin mutluluk düzeyinde farklılık vardır. İşgörenlerin mutluluk düzeyinde departman değişkenine göre farklılaşma durumunu ölçmek amacıyla one-way anova testi yapılmıştır. Analiz sonuçlarına göre mutluluk algı düzeylerinde anlamlı bir farklılaşma görülmemiştir. Hipotez 11a yeterli kanıtla desteklenememiştir. Hipotez 11b: Departman değişkeni açısından, İşgörenlerin iş tatmini düzeylerinde farklılık vardır. İşgörenlerin iş tatmini algılarındaki farklılaşmayı ölçmek amacıyla yapılan anova testi sonucunda anlamlı bir farklılık gözlenmiştir. Araştırma verilerine göre banket departmanında işgörenlerinin iş tatmini algı düzeyleri $(\bar{x}=3,4233)$ diğer departmanlarda görevli işgörenlere göre daha yüksektir. Hipotez $11 \mathrm{~b}$ yeterli kanitla desteklenmiştir. Tor (2011:112) tarafından yapılan farklı çalışmaların sonuçlarına göre ise, personel olarak, en düşük iş doyumu kalite güvence biriminde, en yüksek iş doyumu teknik biriminde, müdür 
yardımcısı olarak, en düşük iş doyumu pazarlama ve satış biriminde, en yüksek iş doyumu ihracat biriminde, müdür olarak en düşük iş doyumu Ar-Ge biriminde, en yüksek iş doyumu pazarlama ve satış biriminde, koordinatör olarak en düşük iş doyumu teknik biriminde, en yüksek iş doyumu Ar-Ge biriminde, genel müdür yardımcısı olarak en düşük iş doyumu insan kaynakları biriminde, en yüksek iş doyumu ise mali işler biriminde olduğu görülmüştür. Hipotez 11c: Departman değişkeni açısından, işgörenlerin çalışma performansı düzeyinde farklılık vardır. İşgörenlerin çalışma performansı düzeyinde farklılaşmayı ölçmek amacıyla yapılan anova testi sonucunda anlamlı bir farklılık gözlenmemiştir. Hipotez 11c yeterli kanıtla desteklenememiştir.

\section{SONUÇ VE ÖNERİLER}

Neredeyse tamamen insan gücüne dayanan turizm sektöründe en iyi elemanı elinde tutabilmek ve en güzel hizmeti müşterilerine sunabilmek isteyen işletmeler, kıyasıya girdikleri rekabet ortamından ancak işgörenlerin mutlulukları ve iş tatminlerini ön planda tutarak bu rekabet ortamından çıabilir ve maksimum performansı elde edebilirler. Turizm işgörenlerinin mutluluk düzeyleri, iş tatminleri ile iş performansları arasındaki boyutun belirlenmesi için yapılmış olan bu çalışmada, anket formu Ankara şehrinde bulunan 4 ve 5 yıldızlı otellerde işgören personele uygulanmıştır. Araştırmaya katılan turizm işgörenlerinin mutluluk düzeyleri, iş tatminleri ve çalışma performansları arasında anlamlı ilişki tespit edilmiştir. Söz konusu ilişki aşağıda sıralanmıştır.

İşgören mutluluk düzeyi arttıkça işgörenlerin iş tatmin düzeyleri de artmaktadır.

$\checkmark$ İşgörenlerin iş tatmin düzeyleri arttıkça çalışma performansları da artmaktadır.

$\checkmark$ İşgörenlerin mutluluk düzeyleri arttıkça çalışma performansları da artmaktadır.

Araştırmaya katılan turizm işgörenlerinin bireysel özellikleri ile sosyal, kültürel ve ekonomik bazı alt boyutlar arasında farklılıklar bulunmuştur. Söz konusu farklılıklar aşağıda sıralanmıştır.

$\checkmark$ Turizm işgörenlerin iş tatminlerine bakıldığında yaş bazında farklılaşma olduğu görülmüştür. İşgörenlerin yaşları ilerledikçe ve sektördeki tecrübeleri arttıkça iş tatminlerinde ki algılamanın olumlu yönde olduğu görülmüştür.

$\checkmark$ Turizm işgörenlerinin sektördeki çalışma yılı değişkeni ile iş tatminleri arasında farklılık bulunmuştur. İşgörenlerin sektördeki çalışma yılları arttıkça işten aldıkları tatminin de artmakta olduğu tespit edilmiştir.

$\checkmark$ Turizm işgörenlerinin işletmedeki çalışma yılı değişkeni ile iş tatminleri arasında farklılaşma bulunmuştur. Sektördeki çalışma yılı 6 ve 10 yılları arasında olan işgörenlerin iş tatminleri, işletmede daha kısa süreli olan işgörenlere göre algılamaları daha anlamlıdır.

$\checkmark$ Turizm sektöründe işgörenlerin işgören ve yönetici olup olmama durumuna göre iş tatmin algılarında farklılaşma tespit edilmiştir. Turizm sektöründe yönetici pozisyonunda işgören kişilerin iş tatmin algıları işgören statüsünde olan kişilere göre artış göstermektedir.

Çalışanların tutum ve davranışlarından doğrudan etkilenen işletme olan konaklama işletmeleri, müşteri memnuniyeti ve nihayetinde başarı elde edebilmeleri için işgören mutluluğu ve iş tatminlerini dikkate almak ve yükseltmek için çaba harcamak zorundadır. Bu sayede çalışanlarının performanslarını da artırmaları mümkün olabilecektir. Araştırma bulguları da desteklemektedir ki, çalışanların mutluluğu, iş tatminlerini yükseltmekte, iş tatminlerinin yüksek olması ise performanslarını artırmaktadır. Dolayısıyla bu süreç diğer işletmeler için önemli olmakla birlikte konaklama işletmeleri için bir kat daha fazla öneme sahiptir. 


\section{KAYNAKÇA}

Akıncı, Z. (2002). Turizm Sektöründe İşgören İş Tatminini Etkileyen Faktörler: Beş Yıldızlı Konaklama İşletmelerinde Bir Uygulama. Akdeniz İ.İ.B.F. Dergisi, 4, 1-25.

Aristoteles, (2015). Eudemos'a Etik (Çev. S. Babür). Ankara: BilgeSu Yayıncllık.

Aşan, Ö. ve Erenler, E. (2008). İş Tatmini ve Yaşam Tatmini İlişkisi. Süleyman Demirel Üniversitesi İktisadi ve İdari Bilimler Fakülte Dergisi, 13(2), 203-216.

Aşık, N. A. (2010). İşgörenların İş Doyumunu Etkileyen Bireysel ve Örgütsel Faktörleri İle Sonuçlarına İlişkin Kavramsal Bir Değerleme. Türk İdare Dergisi, 467, 31- 51.

Çankaya, Z. C. (2009). Özerklik Desteği,Temel Psikolojik İhtiyaçların Doyumu ve Öznel İyi Olma: Öz Belirleme Kuramı. Türk Psikolojik Danışma ve Rehberlik Dergisi, 4(31), 23-31.

Certel, Z., Bahadır, Z., Saracaloğlu, S. ve Varol, S.R. (2015). Lise Öğrencilerinin Öz Yeterlikilkleri İle Öznel İyi Oluş Düzeyleri Arasındaki İlişkinin İncelenmesi. Eğitim ve Öğretim Araştırmaları Dergisi, 4(2), 2146-9199.

Doğan, T., Eryılmaz, A. ve Ercan, L. (2014). İşe Bağlılı̆̆ın Öznel İyi Oluş Üzerindeki Yordaycı Rolü: Akademisyenler Üzerine Bir Çalışma. Gazi Üniversitesi Endüstriyel Sanatlar Eğitim Fakültesi Dergisi, 33, 48-57.

Eryılmaz, A. (2010). Ergenlerde Öznel İyi Oluşu Artırma Stratejilerinin Kullanma ile Akademik Motivasyon Arasındaki İlişki. Klinik Psikiyatri Dergisi, 13, 77-84.

Eğinli, A. T. (2009). Çalışanlarda İş Doyumu: Kamu ve Özel Sektör İşgörenlarının İş Doyumuna Yönelik Bir Araştırma. Atatürk Üniversitesi İktisadi ve İdari Bilimler Dergisi, 23(3) 35-52.

Işık, Z., Çetinkaya, N. ve Işık, M. F. (2017). Mutluluğun İş Tatmini Üzerindeki Rolü: Erzurum İli Palandöken Kış Turizm Merkezinde Yer Alan Konaklama İşletmelerindeki Kadın İşgörenlar Üzerine Bir Uygulama. Atatürk Üniversitesi Sosyal Bilimler Enstitüsü Dergisi, 21(2). 457-471.

Kahya, C. (2013). Örgütsel Sinizm, İş Performansını Etkiler Mi? İş Tatmininin Aracılık Etkisi, Küresel İktisat ve İşletme Çalışmaları Dergisi, 2(3), 34-46.

Kangal, A. (2013). Mutluluk Üzerine Kavramsal Bir Değerleme ve Türk Hane Halkı İçin Bazı Sonuçları. Elektronik Sosyal Bilimler Dergisi, 12(44), 214-233.

Karasakaloğlu, B. (2016). İş Yaşam Kalitesi ve Psikolojik İyi Oluş İlişkisi:Konklama İşletmeleri İşgörenları Üzerine Bir Araştırma. Akademik Sosyal Araştırmalar Dergisi, 4(38), Aralık, 2016, 227-294.

Keleş, H. N. (2017). Anlamlı İş İle Psikolojik İyi Oluş İlişkisi. The Journal of Happiness \& Well-Being, 5(1), 154-167.

Keser, A. (2005). İş Doyumu ve Yaşam Doyumu İlişkisi: Otomotiv Sektöründe Bir Uygulama, Çalışma ve Toplum Dergisi, 4, 77-96.

Kıngır, S. ve Taşkıran, E. (2006). Performans Değerleme Çalışmalarına İlişkin İşgören Görüşlerinin Belirlenmesine Yönelik Bir Araştırma. Afyon Kocatepe Üniversitesi, İ.İ.B.F. Dergisi, 8 (1), 195-216.

Koç, H., Yazıcıŏlu, İ. ve Hatipoğlu, H. (2009). Öğretmenlerin İş Doyum Algıları İle Performansları Arasındaki İlişkinin Belirlenmesine Yönelik Bir Araștırma. OMÜ Eğitim Fakültesi Dergisi, 28, 13-22.

Köroğlu, Ö. (2011). İş Doyumu Ve Motivayon Düzeylerini Etkileyen Faktörlerin Performansla İlişkisi, Turist Rehberleri Üzerine Bir Araştırma. Doktora Tezi, Balıkesir Üniversitesi, Turizm İşletmeciliği Ana Bilim Dalı.

Özgen, M.K. (2005) Farabi'nin Mutluluk Anlayışı. Doktora Tezi, Erciyes Üniversitesi, Sosyal Bilimler Enstitüsü, Felsefe ve Din Bilimleri Anabilim Dalı.

Özmuaf, N. M. (2007) Örgütlerde Bireysel Performans Unsurları ve Çatışma, C.Ü.İ.I.B.F. Dergisi, 8(2), 41-60.

Servet, O. (2017). Mutluluğun Türkiye'deki Belirleyenlerinin Zaman İçinde Değişimi. Akdeniz İktisadi ve İdari Bilimler Fakültesi Dergisi, 35, 16-42. 
Toker, B. (2007). Demografik Değişkenlerin İş Tatminine Etkileri: İzmir'deki Beş ve Dört Yıldızlı Otellere Yönelik Bir Uygulama. Doğuş Üniversitesi Dergisi, 8 (1) ,92-107.

Tor, S. S. (2011). Örgütlerde İş Tatminini Etkileyen Demografik Faktörler ve Verimlilik. Yüksek Lisans Tezi, Karamonuğlu Mehmet Bey Üniversitesi, Sosyal Bilimler Enstitüsü, İşletme Ana Bilim Dalı.

Uludağ, G. (2018). Örgütsel Bağlılık İle İşgören Performansı İlişkisini İncelemeye Yönelik Bir Alan Araştırması, Bitlis Eren Üniversitesi Sosyal Bilimler Enstitüsü Dergisi, 7(1), 171-193.

Uslu, N. B. (2018). Farabi ve Aristoteles ‘Te Mutluluk Ahlakı. Kırıkkale Üniversitesi, Sosyal Bilimler Dergisi, 8(2), 469-480.

Ünsar, S., Taştan, İ., Ünsar, S. ve Dindar, İ. (2010). İş Tatmini Düzeyleri Ve Etkileyen Etmenler, Sağlık Sektöründe Bir Alan Araştırması, Verimlilik Dergisi, 1-14.

Yurcu, G., ve Atay, H. (2015). Çalışanların Öznel İyi Oluşunu Etkileyen Demografik Faktörlerin İncelenmesi: Antalya İli Konaklma İşlemeleri Örneği. Manas Sosyal Araştırmalar Dergisi, 4(2), 17-34.

Yüksekbilgili, Z ve Akduman, G. (2015). Kuşaklara Göre İşkoliklik. Adıyaman Üniversitesi, Sosyal Bilimler Enstitüsü Dergisi, 2015(19), 415-440. 